\title{
ACTIVATING EFL LEARNERS BY INTEGRATING TEAM-BASED LEARNING WITH COLLABORATIVE STRATEGIC READING
}

\author{
Khadijah Maming \\ Universitas Muhammadiyah Parepare \\ email: khadijahmaming@gmail.com
}

\begin{abstract}
Team-Based Learning (TBL) is one of active learning strategies that build on individuals' strengths by allowing them to collaborate and work as a team to achieve common learning objectives. TBL is a cooperative learning strategy was introduced to encourage students become active learners rather than be passive recipients of information. It is generally based on the principle that students working together as a cohesive team are able to achieve higher levels of learning. The lecturer's role essentially is as facilitator. In order to activate the participation of EFL learners in classroom and improve their reading comprehension ability, the researcher conducted a research to find out good impacts of TBL integrated with Collaborative strategic reading toward the English Education Department students in Indonesia as EFL learners. The researcher applied a quasiexperimental method. The students started reading activity by previewing the text, clicking (what vocabulary the students understand), clunking (what vocabulary the students don't understand), getting the gist, wrapping up and done cooperatively. Findings show that TBL integrated with Collaborative strategic reading can activate the participation of EFL learners in the classroom and improve their reading comprehension ability. They also have better achievement than the students taught by conventional learning.
\end{abstract}

Keywords: team-based learning, collaborative strategic reading, EFL, active learning

\section{MENGAKTIFKAN BEMBELAJAR BAHASA INGGRIS SEBAGAI BAHASA ASING (EFL) DENGAN INTEGRASI ANTARA PEMBELAJARAN BERDASARKAN TIM DENGAN MEMBACA STRATEGIS KOLABORATIF}

\begin{abstract}
Abstrak
Pembelajaran Berdasarkan Tim (PBT) adalah salah satu strategi pembelajaran yang membangun kekuatan individual dengan membiarkan pembelajar bekerja secara kolaboratif sebagai suatu tim untuk mencapai tujuan belajar bersama. PBT adalah pembelajaran kooperatif yang ditujukan untuk mendukung pembelajar menjadi pembelajar aktif dari pada sekedar penerima informnasi pasif. TBL secara umum didasarkan pada teori bahwa pembelajar yang belajar secara bersama sebagai satu tim kohesif akan mencapai tingkat pembelajaran yang lebih tinggi. Peran dosen secara esensial adalah sebagai fasilitator. Untuk meningkatkan partisipasi pembelajar bahasa asing (EFL) dan meningkatkan keterampilan membaca mereka, peneliti melakukan penelitian untuk menemukan
\end{abstract}


dampak positif PBT yang diintegrsikan dengan membaca strategis kolaboratif untuk mahasiswa Jurusan Pendidikan Bahasa Inggris di Indonesia. Peneliti menggunakan metode kuasi-eksperimental. Mahasiswa membaca dengan memprevieu teks dan menandai kosa kata yang diketahui dan tidak diketahui, memahami inti bacaan, dan membuat rangkuman secara bersama. Temuan penelitian menunjukkan bahwa strategi PBT yang diintegrsikan dengan membaca strategis kolaboratif dapat meningkatkan pertisipasi pembelajar di dalam kelas dan meningkatkan keterampilan membaca mereka. Mahasiwa memiliki pencapaian belajar yang lebih tinggi daripada mereka yang belajar dengan metode konvensional.

Kata kunci: pembelajaran berdasarkan tim, membaca strategis kolaboratif, EFL, pembelajaran siswa aktif

\section{INTRODUCTION}

Reading becomes a crucial language skill need to be activated in English instruction process. There are many information and insights can be acquired to enlarge our mind through reading activities. In addition to the reading activities, all people could develop their thinking ways, attitude, behavior, learning styles, life principles in which those are needed to build up and continue the personal growth and society growth. In fact, reading is a source of information. Reading for general comprehension is a competence including the deep comprehension and understanding on the content of the text. As the active readers, an important thing to be obligation to do is acquiring the overall understanding of the text.

Reading can be a processing activity for students because they are listing, understanding, comprehending, examining, interpreting, and answering many things on the texts that they are reading. Hence, reading is categorized as an active language activity. It really needs the students' activeness and enthusiasm when they are facing reading texts. An easy be- ginning in reading comprehension activity may be done is listing and understanding the meaning of difficult words covered in reading texts. Through listing and understanding the words' meanings, it can ease the foreign language learners to comprehend the sense of reading texts. Besides, the students also have to be capable to indicate and comprehend the main clue of reading texts. Consequently, King and Stanley (1982) stated that if we are reading for the ideas contained in the reading texts. Not all the ideas are equal importance. Efficient readers comprehend all contents of the written texts, not only the ideas of text writers but also its influential effects as expressed by the author.

According to Grab (2002) in Richards and Renandya (2002) that in many second or foreign language teaching and learning atmosphere, reading is considered as an essential focus to be study and researched. In this case, it is caused of several reasons such as reading instructional model need to be extended and reading instructional materials need to be developed. Additionally, there are many 
people asserted that reading is one of their preferences and hobbies. The people stated that they want be able to read indicated some reasons covering for obtaining information, for enjoyment, for profession and also for informal and formal situation. In fact, the majority of EFL situations expected to the students have good competence in reading skill. However, there are many students have unsatisfied reading skill. Therefore, an essential thing to be studied closely is how to create interesting and enjoyable reading activities for students in order to promote the students' reading comprehension skill. From this view, it can be said that if we want comprehend the reading texts easily so, it is important to present good teaching materials and activities.

Reading is very important to anybody who want to develop the thought horizon. Everyone should have the ability to read the English written forms comprehensively especially in English texts in which in this digital era, the most of the scientific books are written in English. Heinemann (2009) stated that reading is an action process determined by the extent of the reader's thoughts, psychological aspects and beliefs that bring to the acquisition of insight. It is highly needed the competence in processing the text content including analyzing and evaluating the text senses. Through reading, the people can also obtain information which can help them understand and solve various problems which come constantly in their lives, live wise the students at college or university should conceive of how important reading in English language learning. Therefore, it is recommended to the all students to develop their know- ledge in term of reading and comprehending some scientific books, simple stories, magazine, scientific articles, newspaper and other reading materials in which potentially can expand their knowledge in many aspects of science.

Moreover, the students should own high motivation in understanding the text. A student's mindset should be changed that they just want to read if the content of the passage is interested for them or they read because they want to know the content of the text. A student in class usually read if the lecturer asks to do it. To make reading successful, to make reading pleasurable, it requires an investigation of finding out what internal needs and interests to motivate the students to be active readers. The students have to be involved fully on whatever kinds of reading they are reading. In other words, the students are encouraged to be active readers. The people often assert reading as a passive activity. It means that reading process only without expectation to comprehension of every part in reading texts. The students should keep in their mind that reading activities means make interaction with the reading texts. Some aspects of the interactions with the text are finding key words and ideas, looking up unfamiliar words, comprehending the main idea of texts, and recording the questions and comments. From this view, the researcher is inspired to conduct a study focused on activating the EFL learners in reading activity. In order to they will be active readers as the teachers' expectations.

To succeed the reading activity, the lecturer or teacher should pay attention for the strategy and materials. The key to 
create effective reading activity in the classroom is creating the comfortable atmosphere that helps the EFL learners analyze and identify key elements form the reading texts. Additionally, the students need a good learning strategy to comprehend the whole texts easily, for example knowing the meaning of each word, finding in a reading text. They also need a learning model that give chance to discuss and share with their friends. In other words, they like working in cooperative learning because it eases them to comprehend the whole texts.

There are many activities can be applied in activating EFL learners in reading class, such as Team-Based Learning (TBL) and Collaborative Strategic Reading (CSR). This study integrated Teambased learning (TBL) and Collaborative Strategic Reading (CSR) as effective reading activities in classroom. Teambased learning (TBL) is a collaborative learning strategy considered to motivate the EFL learners become active learners and not passive learners who just read without comprehending. Collaborative learning strategies are generally based on the principle that students communicate and discuss together as an interdependent group to occupy the reading learning goals. This strategy is potentially establishing the students' powers in reading activity and empowering the students' socialization ability in cooperatively reading activity. This integrated strategy is believed give impacts on reading comprehension skill improvement.

Klingner and Vaughn (2001) noted that collaborative strategic reading facilitates the students to use comprehension strength related to learning process co- operatively. The students implemented some learning activities including previewing and brainstorming the text; giving contributive feedback, there is "click" means get the points or "clunk" means do not get points until the last part of every paragraph; then "getting the digest" means indicating the main points and the most important parts of the text and the last is "concluding" means investigating the key ideas in term of main ideas. Some views related to the concepts of reading, such as Janet Swaffar (2010) explained that reading is a simple process to investigate and acquire meanings a text. Reading involves the cognitive skills including, understanding, comprehending, analyzing, synthesizing, and evaluating. Then, Mikulecky (2008) stated that reading is a conscious and unconscious thinking process. The readers applied many strategies to build up the meaning of author's assumption and then to be interpreted by readers. The readers are supposed to be able to empower their knowledge about what have they known regarding the readings and prior experience to comprehend the text contents.

Furthermore, Kozak (2011) confirmed that reading is a language skill which allowing the readers to acquire a message, recognizing the written sentences and paragraphs, understanding the meaning and also interpreting the sense of texts. He also stated that reading is a complicated activity that involves both perspective and mind. It means how the students voiced their perception and elaborate their thought toward the text content. Reading consists of two connected processes namely word introduction and comprehension. Word introduc- 
tion refers to the process of perceiving how written symbols associate to oral language. Comprehension refers to the process of making sense of words, sentences, paragraphs and connected text. It is also noted that reading comprehension is a dialogue activity between an author and a reader. The learning activity really needs ability to communicate with an author while reading silently. It is a complex process which the reader employs his/ her material content to obtain from written material. The researcher expected in this study the students have to capability in interpreting reading texts and then comprehension could be one of effective outputs from the integrated strategies implemented by the students.

Moreover, reading comprehension is the power on some essential points (Davis in Paris, 2005), namely; interpreting the meaning from written texts, guessing word meaning in context, identifying the main idea, recognizing passage organization, interpreting the author's purposes, recognizing the message, determining cause-effect relation, recognizing literary devices, and drawing inferences. Duffy (2009) affirmed reading comprehension must be proactive that means the readers actively thinking and monitoring the meaning of texts. The readers' interpretation is really needed to control prior knowledge. Besides, the readers are smart in making interaction with the texts author. Also, they have to be skillful in describing images or pictures provided.

Then, Anderson (2005) highlighted comprehension levels as follows;

a. Reading the outlines in which this level expects a reader to comprehend what the author asserted. A reader is supposed to recall what the author explicitly states in writing.

b. Reading between the outlines, this level is higher and more complicated than reading the outlines. A reader is recommended to understand what the authors mean not just what the author asserted when a reader comprehended the lines, he/she then tried to make interpretation between the lines.

c. Reading beyond the outlines. This level is the highest from two others. A reader at this level is drawing inferences and making generalization on what the readers have read.

Then, Harmer (1998) enlarged the principles of reading namely reading activity is an proactive skill, the students have to involve their selves on what they are reading and interpreting the text meanings, the student are encouraged to be active in responding the content of texts, the students are supported to be able to predict the explanation of text contents, reading class should breading class e organized with the various, challenging and attractive tasks, and also reading class needed the English teachers that can provide and manage class sequence activities successfully. From those explanations about the principles of reading, the researcher assumed that reading is an active skill for the students that hope they competently make prediction about the topic of the text before reading and give response about the content of the reading text, also give the students chance for expressing their ideas after reading. Therefore, the teachers have chronological learning sequence in delivering teach- 
ing and learning process of reading comprehension skill by implementing a good method, strategy, media, or technique into interesting class.

Michaelsen (2008) stated that implementing TBL typically requires activating the learning activities and finishing the assigned exercises cooperatively. This TBL strategy is also very potentially to increase the students' reading comprehension competence. TBL enables the students to cooperate as a solid team particularly in reading activities in classroom. Moreover, Brame, CFT Assistant Director argued that team-based learning is an organized form of small group learning that supports the students to elaborate and relate their voices to accomplish the assigned works. The students are organized strategically into four until five students in a group. In class situation, the students are sitting together with their group and then creating discussion each other. Then, Hrynchak and Batty (2012) proposed that team-based learning relates with the main elements of constructivism approach based learning, in which the orientation is on the deep understanding of information acquired by the learners. Their argument is mentioned as follows; the teacher plays a main role in facilitating learning, the learners are prepared to open their thoughts in constructing latest understanding, deep comprehension on given reading texts during the learning process run, a focus on relevant problems accompanied by group interaction promotes learning. and learning requires reflection.

Team-based learning is compatible with the all of these elements. The teacher arranged the learning goals and selects the issues in which the students focus on learning issues and then acts as a guide for teams work with the mission to finish the learning issues. Team-based learning provides several opportunities for learning and communicating actively whether in pre activity, whilst activity and post activity. TBL also prepares the students to make reflection on their interaction pattern and work result that have been finished together.

Bremer, Vaughn, Clapper, and Kim (2001) revealed that collaborative strategic reading by elaborating with the concept of team-based learning. They highlighted that reading comprehension practice combined two instructional elements namely reciprocal teaching and cooperative learning in term of pairing or small group. In reciprocal teaching, teachers and students created active dialogue related to main features of text through summarizing, questioning, clarifying, and predicting. More recent studies using reciprocal teaching have been reported in which it is effective to apply in middle school and high school readers. Through a number of research trials, collaborative strategy reading has been refined and currently consists of four comprehension strategies that students apply before, during, and after reading in small cooperative groups. These reading strategies are: (a) preview (before reading), (b) click and clunk (during reading), (c) get the gist (during reading), and (d) wrap up (after reading).

\section{METHOD}

In this study, the researcher applied quasi experimental design, applying the two group of pretest and posttest design. 
This study was conducted in six times meetings in applying Team-Based learning (TBL) integrated with Collaborative Strategic Reading (CSR) in activating the EFL learners particularly in experimental group. Conventional way applied in control group. In this case, the researcher implemented three phase technique in which it is very generally way that the majority of teachers applied in their English class. The researcher used some different topics of reading texts in every meeting to the both of groups. Before doing treatment to the both groups experimental and control group, the students were instructed to complete the pretest in which covered test of reading comprehension including multiple choice, true false form and essay form. Also, after getting treatment, they were instructed to complete posttest of reading comprehension skill. The content of posttest was similar with the content of posttest. The data obtained from pretest and posttest were analyzed quantitatively and interpreted qualitatively. The quantitative analysis of research data was done in Microsoft excel using some formula available in Microsoft Excel program.

Additionally, to test hypothesis, the researcher employed one tail hypothesis with $=0,05$ and degree of freedom $(\mathrm{df})=$ $\mathrm{n}_{1}+\mathrm{n}_{2}-2$. The statistical hypothesis of this research was $\left.\mathrm{H}_{1}=\mu_{1}\right\rangle \mu_{2}$ and $\mathrm{H}_{0}=$ $\mu_{1}\left\langle\mu_{2}\right.$ where;

$\mu_{1}=$ The students who are taught by implementation of team-based learning integrated collaborative strategic reading.

$\mu_{2}=$ The students who are taught by implementation of three phase technique.
The explanation of this statistical hypothesis was;

a. If t-test is no higher than t-table, null hypothesis (Ho) is accepted and alternative hypothesis $\left(\mathrm{H}_{1}\right)$ is rejected. It indicates that students who are taught by the implementation of team-based learning integrated with collaborative strategic reading is not better than the students who are taught by the implementation of three phase technique. It means that the implementation of team-based learning integrated with collaborative strategic reading is not able to improve the reading comprehension skill of the students.

b. If t-test is higher than t-table, alternative hypothesis $\left(\mathrm{H}_{1}\right)$ is accepted and null hypothesis (Ho) is rejected. It indicates that the students who are taught by implementation of teambased learning integrated with collaborative strategic reading is better than the students who are taught by implementation of three phase technique. It means that the implementation of team-based learning integrated with collaborative strategic reading is able to improve the reading comprehension skill of the students.

This study has independent variable, dependent variables and confounding variables. The independent variable was the implementation of team-based learning integrated with collaborative strategic reading (CSR). Dependent variable was the students' reading comprehension skill. While, one of the confounding variables was the teacher's way in delivering implementation of integration TBL and CSR to teach and learn the students read- 
ing comprehension skill. The researcher's way in implementing TBL integrated with CSR have to be interesting, communicative and interactive. The researcher's way has high effect in succeeding teaching and learning process. The researcher was expected to be competent in organizing English class by implementing integration of TBL and CSR. It must be created active English learning atmosphere in order to the students feel enjoyable, motivated, encouraged in improving their reading competence. Therefore, the researcher managed and organized the class effectively and efficiently. Also, the important thing was implementation of TBL integrated CSR based on student centered approach so that the students do more the learning tasks and minimalize the researcher's talks.

In the first meeting instruction process, the researcher facilitated an explanation about the main concepts of TeamBased learning (TBL) and Collaborative Strategic Reading (CSR). The reading class was formed into some groups, in which every group consist of three students. The students were asked to do reading activity by following the steps of CSR. The second meeting until the sixth meeting, the researcher applied TBL integrated with CSR in highlighting or underlining keywords and ideas, looking up unfamiliar vocabulary words, comprehending the reading texts, looking for clues throughout the texts and recording your questions and comments. While the learning process was conducting, the researcher observed the subjects of this research, such as; their activeness, their at- tendance and their seriousness. The students' activities are;

a. Dividing class into several groups, every group consists of five students.

b. Preview (before reading): the students thought what they will read namely brainstorming and predicting).

c. Click (what vocabulary you understand) and clunk (what vocabulary you do not understand) during reading activity, to guess the meaning of text, and the students can open their dictionary.

d. Get the gist (during reading): in this case, the click and the clunk helped students to identify main ideas.

e. Wrap up (after reading): students generated questions by using $5 \mathrm{~W}+1 \mathrm{H}$ Question.

f. Preparing for class presentation.

g. Answering some questions based on reading texts.

In control class, the treatments were conducted through conventional way. Here, conventional way implemented in control group was three phase technique including pre activity step, whilst activity step and post activity step. In details, conventional way was demonstrated in control group in which the class was divided into some groups, after that they were given reading texts and read the texts. Then, they were instructed to express their answers based on the list of questions in reading texts. In analyzing the data collecting of the test, the researcher applied quantitative approach. Some formulas applied in this study used to tabulate the research data. 
Categorizing scores based on the gained students' score in pretest and posttest. In objective test such as multiple choice test and true false test, the students got score 1 if their answer right and got zero if their answer wrong. Then, objective test was analyzed followed the rule of subjective test assessment. Below was the students' level achievement after their scores accounted, scored, analyzed and then classified. Table 1 regarding to level of students' achievement was based on Academic Rule of UMPAR, 2008

In finding the mean score of pretest and posttest of experimental group, the researcher used the formula stated by Gay Mills, and Airasian (2016). In the last meeting, the researcher distributed them questionnaire to achieve the students' response and attitude toward the application of team-based learning (TBL) integrated with collaborative strategic reading (CSR). In analyzing the data collected from observation and questionnaire, the researcher used quantitative approach. The researcher used Likert Scale (Gay, Mills and Airasian, 2006) to tabulate and analyze the data obtained from observation and questionnaire. From ob- servation sheet, the findings were analyzed to get information about the students' behavior, activeness, attention and enthusiasm in learning process.

\section{FINDINGS AND DISCUSSION Findings}

From the data of research, this study reveals the results such as the students' pretest, the students' posttest, and the ttest. In pre-test, the researcher obtained the raw data from the students' work results in doing objective tests and subjective test of students' reading comprehension test. Then, the students' raw data were analyzed, categorized and interpreted. Similarly, the research findings from posttest were also analyzed and interpreted. In this pretest, the researcher employed reading test to the students before giving them treatment. The percentage of the students' scores in experimental group and control group particularly in pretest could be seen in table 2 . The treatment implemented in experimental class was teaching and learning process by implementing team-based learning integrated with collaborative strategic reading.

Table 1. Level of Achievement

\begin{tabular}{llll}
\hline Range & Classification & Category & Score \\
\hline $85 \%-100 \%$ & Very Good & A & 4 \\
$70 \%-84 \%$ & Good & B & 3 \\
$55 \%-69 \%$ & Fair & C & 2 \\
$50 \%-54 \%$ & Poor & D & 1 \\
$0 \%-49 \%$ & Very Poor & E & 0 \\
\hline
\end{tabular}


Table 2. The Percentage Score of Reading Comprehension of Experimental and Control Class in Pretest

\begin{tabular}{lllllll}
\hline No & Classification & Scores & \multicolumn{2}{c}{ Experimental Class } & \multicolumn{2}{c}{ Control Class } \\
& & F & $\mathbf{( \% )}$ & F & (\%) \\
\hline 1 & Very Good & $85 \%-100 \%$ & 0 & 0 & 0 & 0 \\
2 & Good & $70 \%-84 \%$ & 2 & 10.52 & 0 & 0 \\
3 & Fair & $55 \%-69 \%$ & 7 & 36.84 & 9 & 70.58 \\
4 & Poor & $50 \%-54 \%$ & 8 & 42.10 & 10 & 5 \\
5 & Very Poor & $0 \%-49 \%$ & 2 & 10.52 & 1 & 5.88 \\
& Total & & 19 & 100 & 20 & 100 \\
\hline
\end{tabular}

The experimental and control group are still low in reading comprehension before giving treatment. The most of students categorized poor classification by seeing the table in experimental group and control group. In experimental class, there are 8 of 19 students categorized poor classification. Only 2 students are in good classification. But, in control class there are 10 of 20 students are in poor classification. It means that, the both of groups are almost similar on reading comprehension ability. In post-test, the researcher acquired the raw data taken from the students' work results in doing objective tests and subjective test of students' reading comprehension test. Then, the researcher analyzed, classified and interpreted the students' scores of posttests. Posttest scores were acquired from reading comprehension test given to the students.

Table 3. The Percentage Score of Reading Comprehension of Experimental and Control Class in Posttest

\begin{tabular}{lllllll}
\hline No & Classification & Scores & \multicolumn{3}{c}{ Experimental Class } & \multicolumn{2}{c}{ Control Class } \\
& & F & (\%) & F & (\%) \\
\hline 1 & Very Good & $85 \%-100 \%$ & 10 & 52.63 & 0 & 0 \\
2 & Good & $70 \%-84 \%$ & 5 & 26.31 & 3 & 15 \\
3 & Fair & $55 \%-69 \%$ & 2 & 10.52 & 16 & 80 \\
4 & Poor & $50 \%-54 \%$ & 1 & 5.88 & 1 & 5.88 \\
5 & Very Poor & $0 \%-49 \%$ & 1 & 5.88 & 0 & 0 \\
& Total & & 19 & 100 & 20 & 100 \\
\hline
\end{tabular}


Table 3. shows that the student's achievements improve after giving treatment. In experimental class. There are ten students got very good classification although there are two students classified poor achievement. It is different with control class, no student categorized very good classification. Although, there were three students categorized good classification and sixteen students are fair classification. It indicated that the experimental group has more significant improvement than control group. From this point of view, the majority of students in experimental group categorized good and very good classification. But, it means that the students' achievement got improvement from pretest and posttest.

Table 4. The Mean Score and Standard Deviation of Pretest

\begin{tabular}{llll}
\hline No & Group & $\begin{array}{l}\text { Mean } \\
\text { Score }\end{array}$ & $\begin{array}{l}\text { Standard } \\
\text { deviation }\end{array}$ \\
\hline 1. & Experimental Class & 54.52 & 25.43 \\
2. & Control Class & 53.09 & 8.96 \\
\hline
\end{tabular}

Table 4. indicated that the mean score and standard deviation of the pre-test both in experimental class and control class were not significantly different. It means that the reading comprehension of the students both in experimental class and control class have the similar performance before giving treatment. However, the students reading comprehension performance in experimental group is more various than in control group.

Table 5. The Mean Score and Standard Deviation of Posttest

\begin{tabular}{llll}
\hline No & Group & $\begin{array}{l}\text { Mean } \\
\text { Score }\end{array}$ & $\begin{array}{l}\text { Standard } \\
\text { deviation }\end{array}$ \\
\hline 1. & Experimental Class & 81.57 & 15.67 \\
2. & Control Class & 65.83 & 7.08 \\
\hline
\end{tabular}

The table 5. explained that in experimental class getting improvement significantly than control class. It is proved by the score improvement in experimental is higher than control class. It means that the reading comprehension of the students can improve by implementing CSR integrated TBL. Besides, from the score of standard deviation showed the students' reading comprehension ability in posttest was less various than in pretest.

Table 6. The Improvement of Students' Score for Both Groups

\begin{tabular}{lll}
\hline No & Group & $\begin{array}{l}\text { Improvement } \\
\text { Point }\end{array}$ \\
\hline 1. & Experimental Class & 27.05 \\
2. & Control Class & 9.6 \\
\hline
\end{tabular}

Table 6 described the improvement of students' scores for both groups. It indicated that the improvement point of the students' score in experimental group is better than control group. It indicated that the implementation of team-based learning integrated with collaborative strategic reading has been implemented in reading class of experimental group is better than implementation of conventional method implemented in control group. To know whether or not the point of mean difference of experimental and control group was statistically significance in which the level of significant 0.05 , degree of freedom $\left(n_{1}+n_{2} 2\right)=19+$ $20-2=37$. The researcher tested the hypothesis, by applying t-test formula at the level of significance with $\alpha=0,05$ and with degree of freedom $=37$. The t-test value of the students' pretest and posttest were shown in following table. 
Table 7. The t-Test Value of the Students

\begin{tabular}{lll}
\hline $\begin{array}{l}\text { Level of } \\
\text { significance }\end{array}$ & $\begin{array}{l}\text { t-test } \\
\text { value }\end{array}$ & $\begin{array}{l}\text { t-table } \\
\text { value }\end{array}$ \\
\hline 0.05 & 3.97 & 2.021 \\
\hline
\end{tabular}

After applying t-test independent sample, it found the difference of the students' reading comprehension between the experimental class and control group. In this way, it resulted the t-test value (3.97) is better than t-table value (2.021). It confirmed that the null hypothesis was rejected and the alternative hypothesis was accepted. Hence, the researcher concluded that the students who were taught by implementing team-based learning integrated with collaborative strategic reading was better than the students who were taught through conventional way in term of three phase technique. There were improvements of the students' scores from pretest to posttest since team-based learning integrated with collaborative strategic reading enhanced the students' reading comprehension performance, engagement in learning atmosphere and also motivation to study.

\section{Discussion}

According to the findings, it noted that teaching reading comprehension skill through the implementation of team-based learning integrated with collaborative strategic reading is able to promote the EFL students' reading comprehension skill. It revealed the implementation of team-based learning integrated with collaborative strategic reading is better than implementation of conventional way in reading class. This statement is proved by the result of test of the students' achievement before and after they are guided a treatment, their grade achievement is significantly different. The students' reading comprehension skill taught through Team-based learning integrated with collaborative strategic reading has high improvement than the students' reading comprehension skill taught through conventional way.

During the research process, the students were distributed pretest in both of experimental group and control group. Pretest used in this study was the reading test in form of narrative texts to find out the initial knowledge of the students before facilitating them with treatment. Based on results, it found in pretest of experimental class, the students reading comprehension skill was still poor which could be proved by percentage or frequency of some students still got poor classification of reading comprehension score. Meanwhile, in control class was almost similar with the experimental class in which the students' reading comprehension was good enough which could be proved by the percentage or frequency where some students got very poor classification of reading comprehension score.

After giving pretest, the students in experimental and control class got facilitation of treatment. In this case, teaching reading through team-based learning integrated with collaborative strategic reading in experimental class and teaching reading through conventional way namely three phase technique in control class. After treating with instructional activity, the students were distributed posttest to both classes. Posttest was assigned to investigate the progress of students' read- 
ing comprehension performance after giving different treatment. The result of findings in posttest of experimental class proved that the students' reading comprehension was better than the result in pretest. The different result was showed in control class. Based on the result of finding in posttest of control class, it also shows that the students' reading comprehension was higher than result in pretest as well as experimental class. However, the improvement of students' score in control class did not significantly improve instead of the experimental class.

The result of finding related to the students' reading comprehension of experimental group and control group showed that the reading comprehension in the both class had improved with the different progress. In experimental class, students' score had improved significantly because students given a treatment with interpretation of visual aids such as pictures. It was proved by the students become more aware of how texts are constructed and make them more critical of text. This finding supports what Bremer, Vaughn, Clapper, and Kim (2001) stated about implementation of collaborative strategic reading integrated with teambased learning can activate the students' initial knowledge, to facilitate them in expressing predictions about what they will read, and to generate interest. In detail, this is a part of preview consists of two activities namely brainstorming activity and predicting activity.

The researcher presented previewing activity to the students by asking them to think about the previews they have seen at the movies. The researcher instructed the students to tell what they have learned from previews by asking questions such as, "Do you learn who is going to be in the movie?" or "Do you learn in what historical period the movie will take place?" Then the teacher asked them to skim information such as headings, pictures, and words that are bolded or underlined to determine (a) what they know about the topic and (b) what they think they will learn by reading the text. Besides, the activity of click and clunk during reading is a way that teaches students to monitor their understanding during reading. The teacher describes a click as something that "you really get. You know it just clicks." After students understand, the teacher explains a clunk: "A clunk is like when you run into a brick wall. You just really don't understand a word the author is using. That's a clunk." This is also part of collaborative strategic reading.

The students were directed to get the gist or key. It is a good way to assist the students in identifying main ideas during reading activity. The recommended ways to identify the main idea is to answer the questions that asking about description of the texts, the content of texts, the essential points included in the texts, and so on. How to get the digest was done by teaching the students to focus on every paragraph in the texts. When the students are reading the given texts, the researcher instructed them to look for most important person, place, or thing. Then the researcher continued her instruction to tell the most important things regarding to the person, place, or thing.

In the last activity of reading, the students were instructed to collect all information in a sentence containing ten 
words or less. It is called associating activity conducted in the last phase of collaborative strategic reading. This activity was conducted after reading. The research result supports the statement that associating is a strategy that teaches students to generate questions and to review important ideas in the text they have read. Associating consists of two activities: (a) generating questions, and (b) reviewing. Generating questions mean asking questions by using wh-questions such as who, what, when, where, why, and how. These aimed to enhance the higher thinking skill. The next, the teacher asked the students to arrange the most important ideas from the reading assignment.

From four steps above, the researcher of this study assumed that this strategy involves the students to do three activities, that are before reading activity, during reading activity, and after reading activity. It showed that there is no time for the students to stop to learn during teaching and learning process. It is potentially support the students worked in group and building their vocabulary during reading. Therefore, the researcher implemented this integrated strategy in order to assist the students understand the text easily. Then, the students are more interested in improving their ability in reading comprehension activity. in brief, could be noted that the integration of team-based learning and collaborative strategic reading is potentially activate the students' participation in reading class and develop their reading comprehension competence.

\section{CONCLUSION}

Referring to the research findings and discussion of this study, it could be drawn a conclusion that the implementation of team-based learning (TBL) integrated with collaborative strategic reading is able to develop reading comprehension of the EFL students. Besides, it can activate the students' initial knowledge, the students can recognize the meaning of vocabulary in context, the students are able to find detailed information from the reading texts and also interact actively in small group discussion. Therefore, the implications of this method are development of vocabulary and reading skill, training the students thinking actively, having better comprehension on what they are reading, training them to review important point and having good cooperation between one and other members of groups. However, this method also has some weaknesses, such as; big noise when teaching and learning ran, different point in every group made the students difficult to work together, still more focused on intensive together, sometimes hesitate in communicating more effectively and difficult controlling on the members of every group.

\section{ACKNOWLEDGMENTS}

The writer expresses gratitude to the students of English education study program for their participation during the data collection. The gratitude is also given to the all-academic staffs of Faculty of Teacher Training and Education, Universitas Muhammadiyah Parepare. 


\section{REFERENCES}

Anderson. N. 2005. Exploring Second Language Reading. Canada: Heinle Publishers.

Bremer, C. D., Vaughn, S. Clapper, Ann T., and Kim , Ae-Hwa. (2001). Collaborative strategic reading (CSR): Improving Secondary Students' Reading Comprehension Skills. (Online). http:// www.ncset. org/publications/viewdesc. asp?id=424. Accessed on December $5^{\text {th }} 2015$.

Duffy, G. G. (2009). Explaining Reading: A Resource for Teaching Concept, Skills, and Strategies 2nd Ed. United States of America: The Guildford Press.

Gay, L.R., Mills, G. E., Airasian, Peter. (2006). Educational Research: Competencies for Analysis and Applications (8 ${ }^{\text {th }}$ Edition). Upper Saddle River, New Jersey Columbus, Ohio: Pearson.

Harmer, J. (1998). How to Teach English. New York: Longman Press.

Harmer, J. (2001). The Practice of English Language Teaching (3 ${ }^{\text {rd }}$ Edition). New York: Longman Press ELT.

Healy, C. (2002). Reading: What the Experts Say the Lowdown on the National Reading Pane. PEATC. Online. http:// www.peatc.org./ Fact $\% 20$ Sheets/reading.pdf. Accessed On November $06^{\text {th }}, 2015$.

Heinemann. Ed. (2009). Reading Process. Ohio: Miami University Oxford, (Online). http:// www.heinemann. com/shared/ online resources / e02843/weaver_websample.pdf). Accessed on November14 ${ }^{\text {th }} 2015$.

King, C. and Nancy S. (1982). Building Skills for The TOFL (Test of English as
A Foreign Language). Thomson Litho Ltd: London.

Klingner, J. K., Vaughn, S. (2001). Online. http:// www.readingrockets. org/article/using-collaborative-strategic-reading. Accessed on December $10^{\text {th }} 2015$.

Michaelsen, L. (2008). Team-based learning Health Professions Education. A Guide to Using Small Groups for Improving Learning. United Stated of America: Stylus Publishing, LLC.

Mikulecky, Ed.D., Beatrice S. (2008). Teaching English in a Second. Pearson Education. Online. http:// www. longmanhomeusa.com/content/ FINAL-LO\%20RES-MikuleckyReading\%20Monograph\%20.pdf. Accessed on December 14 2015.

M, Kozak. (2011). The Types of Reading and Exercises for Teaching Reading. Online. http://www.e-osnova.ru/ PDF/osnova_10_0_696.pdf. Accessed on December $20^{\text {th }} 2015$.

P, Hrynchak and H, Batty. (2012). The Educational Theory Basis of Teambased learning. Medical Teacher.

Richards, J. C. and Schmidt, R. (2002). Longman Dictionary of Language Teaching and Applied Linguistics (3 $3^{\text {th }}$ edition). London: Pearson Education Limited.

Swaffar J. (2010). Foreign Language Teaching Methods. Austin.

UMPAR. (2008). Academic Rule of Muhammadiyah University of Parepare. Parepare: UMPAR Press.

Willis, J. (1998). Teaching English Through English, A Course in Classroom Language and Techniques. England: Longman. 